\title{
Domestic Contribution and Constructive Trusts: The Canadian Perspective
}

\author{
Mary Welstead*
}

Early in November 1986, Rosa Becker, the respondent in Pettkus v. Becker, ${ }^{1}$ committed suicide after a twelve year legal battle. ${ }^{2}$ After six years of litigation the Supreme Court of Canada, in 1980, had awarded her $\$ 150,000$ under a constructive trust. She never received payment because the appellant Lothar Pettkus claimed that he did not accept the Supreme Court's ruling. He proceeded to "use every legal tree in the forest of law"3 to evade Rosa Becker's attempts to enforce her constructive trust. On November 5th 1986 she finally gave up her fight.

This article commemorates Rosa Becker. She may only have won a pyhrric victory for herself but she succeeded in changing the law of trusts of property, in the familial context, in Canada. In so doing, she prepared the way for the recognition of domestic contribution as giving rise to a remedial constructive trust. No other commonwealth jurisdiction has accepted domestic contribution alone as grounding a successful plea of a constructive trust. ${ }^{4}$

The acceptance by the Canadian courts of the relevance of domestic contribution in trusts of property in the familial context ${ }^{5}$ has developed over a period of some thirteen years. ${ }^{6}$ The origins of this development are to be found in the dissenting judgement of Laskin J. in Murdoch v. Murdoch. ${ }^{7}$ Laskin J.'s views were approved of by Dickson J. in dicta, in Rathwell v. Rathwell. ${ }^{8}$ It was not, however, until Pettkus v. Becker ${ }^{9}$ that the Canadian Supreme Court was able to

- Of the School of Law, University of Buckingham.

1. Pettkus v. Becker 117 D.L.R. (3d) 257.

2. The Montreal Gazette, 11 th November 1986, p.1 col.1.

3. Ibid. per Gerald Langlois, Rosa Becker's lawyer.

4. See Bums v. Bums [1984]1 All E.R. 244. Domestic contribution might be accepted as a relevant detriment if an express oral agreement exists and in that sense may give rise to a constructive trust: see Grant v. Edwards [1986] 2 All E.R. 426, at p.437 per Sir Nicholas Browne-Wilkinson V.C.. See also n.18, infra.

5. The term familial is used to include all relationships involving emotional, financial and practical interdependancy; see [1979] 31 Fam. Law 244; [1980] C.L.7. 31.

6. John L. Dewar, [1982] 60 Can. Bar Rev. 265.

7. Murdoch v. Murdoch 41 D.L.R. (3d) 367 , at p.377.

8. Rathmell v. Rathwell 83 D.L.R. (3d) 289 , at p.305.

9. Supra n.1. 
escape from the confines of the intention based resulting trust and hold that the concept of the constructive trust based on the principle of unjust enrichment was accepted law in Canada. Five years later, the Supreme Court in Sorochan v. Sorochan ${ }^{10}$ held that the principle of unjust enrichment extended to domestic contributions.

\section{The intention based resulting trust}

Prior to the decision of the Supreme Court in Pettkus v. Becker ${ }^{11}$ the Canadian courts had adopted an artificially extended form of the purchase money resulting trust in the resolution of familial property disputes. In a strict sense this category of resulting trust does not require intention at all; it arises by operation of law. ${ }^{12}$ The principle upon which the purchase money resulting trust is based was stated in Dyer v. Dyer ${ }^{13}$ by Eyre C. B.. He accepted that, "the clear result of all the cases, without a single exception, is that the trust of a legal estate, whether freehold, copyhold, or leasehold; whether taken in the names of the purchasers and others jointly, or in the names of others without that of the purchaser; whether jointly or successive, results to the man who advances the purchase money."14 This resulting trust arises out of Equity's presumption that bargains rather than gifts are intended in such circumstances. The person advancing the purchase money is presumed to have intended that the legal title holder should hold the beneficial title on trust for him. The presumption is rebuttable by evidence of a contrary intention.

The purchase money resulting trust was extended to post acquisition payments provided that the payments were referable to the property. In Gissing v. Gissing, ${ }^{15}$ Lord Diplock recognised that it would be unreasonably legalistic to restrict the purchase money resulting trust to contributions made at the time of the acquisition of the property. He accepted that later financial contributions referable to the property could also lead to a resulting trust. A retrospective inference could be made from these financial contributions that the parties had intended to share the beneficial interest from the time of acquisition. ${ }^{16}$

Professor Donovan Waters has observed that this retrospective inference was, in fact, " ... a constructive trust approach masquerading as a resulting trust approach." ${ }^{\prime \prime}$ He stressed the absence of a common intention, in the majority of cases, at the time the property was acquired. Professor Waters argued that the courts' discovery of an implied common intention from financial contributions was frequently a means of giving the wife a just and equitable share in the disputed asset.

10. Sorochan v. Sorochan 29 D.L.R. (4th) 1, at p.6.

11. Supra n.1.

12. Donovan Waters, (1970) 16 MoGill L. Joum. 188; Donovan Waters, (1975) 53 Can. Bar Rev. 366.

13. Dyer v. Dyer (1788) 2 Cox Eq. Cas. 92, at p.93.

14. Ibid.

15. Gissing v. Gissing [1971] A.C. 886.

16. Ibid., at p. 908

17. (1975) 53 Can. Bar Rev. 366, at p.368. 
Inevitably attempts were made to extend the resulting trust still further and include within its boundaries fact-situations in which a labour contribution or a contribution to general household expenditure had been made. The courts showed a marked reluctance to accept that these contributions could lead to an inference of a resulting trust. ${ }^{18}$ If there was a separate agreement by the parties to share the beneficial interest in property the courts were prepared to accept that this type of contribution could give rise to a resulting trust. Lord Diplock in Gissing v. Gissing ${ }^{19}$ accepted that in circumstances of express oral agreements, "it has been assumed sub silentio that they provide for the spouse in whom the legal estate in the matrimonial home is not vested to do something to facilitate its acquisition, by contributing to the purchase price or to the deposit or the mortgage instalments when it is purchased upon mortgage or to make some other material sacrifice by way of contribution to or economy in the general family expenditure."20

The Canadian Courts claimed to follow the approach of Lord Diplock towards resulting trusts as formulated in Gissing v. Gissing. ${ }^{21}$ An examination of the case law prior to Pettkus v. Becker ${ }^{22}$ suggests that this was not so. Substantial labour contributions were accepted as giving rise to an inference of intention where there was no separate express agreement to share the beneficial interest.

\section{The majority decision in Murdoch v. Murdoch.}

It fell to the Supreme Court in Murdoch v. Murdoch ${ }^{23}$ to decide whether to extend the intention based resulting trust to contributions of non-domestic labour in the absence of a separate express agreement to share the beneficial interest in the property. The appellant wife, Mrs Murdoch, had lived and worked with the respondent, Mr Murdoch, for twenty-one years. During the greater part of that time they lived on ranches which were purchased in the sole name of $\mathrm{Mr}$ Murdoch. There was no express common intention on their part to share the beneficial interest. Nor was there any substantial financial contribution at the time the disputed property was purchased from which such an intention could be inferred. The Supreme Court was prevented from accepting Mrs Murdoch's financial contribution as leading to an inference of a common intention because the trial judge had held that her contribution was a loan. ${ }^{24}$ Mrs Murdoch claimed that her substantial contribution of labour led to the inference that a common

18. See Gissing v. Gissing [1971] A.C. 886; Pettitt v. Pettitt [1970] A.C. 777; Bums v. Bums [1984] 1 All E.R. 244; c.f. Nixon v. Nixon [1969] 1 W.L.R. 1676.

19. Supra n.15.

20. Ibid., at p.905; see also McFarlane v. McFarlane [1972] N.I. 59. It has been suggested that this type of trust is not a resulting trust but a failed express trust given effect by means of estoppel: see C. Harpum, (1982) 2 Oxford fo. Leg. Stud. 277, at p.279, Sir Nicholas Browne-Wilkinson V.C., in Grant v. Edmards [1986] 2 All E.R. 426, at p.437, referred to such a trust as a constructive trust.

21. Supra n.15.

22. Supra n.1.

23. Murdoch v. Murdoch 41 D.L.R. (3d) 367. See also Jacobsen, (1974) 20 McGill L. Joum. 308.

24. Murdoch v. Murdoch 41 D.L.R. (3d) 367, at p.380. 
intention existed between her and her husband that they should share the beneficial interest of the property. She relied on the judgment of the Alberta Court of Appeal in Trueman v. Trueman. ${ }^{25}$ In that case it was accepted that substantial labour by a wife, which would have normally been done by hired hands or her husband, could give rise to a resulting trust of the family homestead.

Mrs Murdoch's labour contribution would have appeared, to most people, to be substantial. She described her work as "Haying, raking, swathing, mowing, driving trucks, and tractors and teams, quietening horses, taking cattle back and forth to the reserve, deworming, vaccinating, branding, anything that was to be done. I worked outside with him, just as a man would ..."26 Mr Murdoch had claimed that such labour was, "just about what the ordinary rancher's wife does". ${ }^{27}$ This view was shared by the majority of the Supreme Court. In the absence of a finding of a substantial labour contribution Mrs Murdoch's claim failed.

By accepting that Mrs Murdoch's labour was that of an ordinary rancher's wife, the Supreme court was able to distinguish the Trueman Case. The claim in Trueman was for a share in the family homestead. The labour of the wife in that case was accepted as substantial and could therefore give rise to an inference of an intention to share in the beneficial interest of that homestead. In Murdoch the interest claimed was a one-half share in all the property of a more substantial commercial enterprise. There was a marked reluctance by the Supreme Court to extend the resulting trust concept to commercial assets even where the family home was part of those assets.

Counsel for the respondent in Murdoch had contended that in the light of the Supreme Court decision in Thompson v. Thompson ${ }^{28}$ the Trueman Case was wrongly decided. Martland J., giving the majority decision in Murdoch, impliedly accepted that Judson J. in Thompson had left open the possibility that a substantial labour contribution could give rise to a resulting trust. Judson J. had held that, in the absence of a financial contribution or other attributes of matrimonial partnership, there could be no resulting trust. It was thus open to the Canadian Supreme Court at some future date to infer an intention to share the beneficial interest in property from other attributes of matrimonial partnership such as a substantial contribution of labour.

\section{The dissenting judgment of Laskin J. in Murdoch v. Murdoch}

Laskin J. in Murdoch v. Murdoch ${ }^{29}$ did not share the trial judge's appreciation of normalcy. He thought that Mrs Murdoch's labour could be characterised as nothing less than extraordinary. As such, it should be treated as no less significant than substantial financial contributions. However, to do that within the framework

25. Trueman v. Trueman 18 D.L.R. (3d) 109. See also Smith v. Ahone 56 D.L.R. (3d) 454.

26. Murdoch v. Murdoch 41 D.L.R. (3d), at p.380.

27. Ibid.

28. Thompson v. Thompson 26 D.L.R. (2d) 1.

29. Murdoch v. Murdoch 41 D.L.R. (3d) 367, at p.377. See also Re Spears v. Levy 52 D.L.R. (3d) 146. 
of resulting trusts was, according to Laskin J., quite artificial. He found it unnecessary to manipulate the resulting trust doctrine any further. He argued forcefully that the doctrine of constructive trusts based on unjust enrichment was to be preferred. This doctrine had neither been pleaded nor argued by the parties. The majority in Murdoch did not respond to Laskin J.'s views.

His dissenting judgment was grounded on the Supreme Court decision in Deglman v. Guaranty Trust Co. of Canada and Constantinea $u^{30}$ which recognised the principle of unjust enrichment, for the first time, as good law in Canada, in the context of quasi-contractual restitutionary claims. Laskin J. held that Mr Murdoch had been unjustly enriched by Mrs Murdoch's substantial contribution of non-domestic labour. A constructive trust arose in these circumstances. Laskin J. was not prepared to extend this principle to purely domestic labour. Such labour might be said to be, "merely a reflection of the marriage bond"31 and could not be translated easily into money's worth as could other types of labour. He was not prepared to view domestic activity as equal to strenuous physical labour. Laskin J.'s judgment served the purpose of averting attention to the mythical nature of the intention based resulting trust in circumstances where the claimant's contribution took the form of substantial labour.

\section{The majority decision in Rathmell $\mathbf{v}$. Rathwell}

A differently constituted Supreme Court in Rathwell v. Rathwell ${ }^{32}$ considered, once again, the applicability of resulting trust principles in the familial context. Until the breakdown of their marriage $\mathrm{Mr}$ and Mrs Rathwell had worked together in a joint farming enterprise. When their relationship came to an end, Mrs Rathwell claimed a half-share in the property, the title of which was in the sole name of Mr Rathwell.

There was the fortuitous distinction between Murdoch v. Murdoch ${ }^{33}$ and the Rathwell Case that Mrs Rathwell had made a limited financial contribution to the property. This contribution was made from the Rathwell's joint account into which they had placed their wartime savings.

In those circumstances the court was prepared to extend resulting trust principles to a fact-situation where the major contribution of the wife was substantial farm labour and domestic labour, albeit in a farm context. It recognised that Mrs Rathwell, "in addition to what might be called ordinary household tasks, took meals to the fields, helped move machinery, raised poultry, acted as back up driver for the bus contract, milked cows, grew a garden and did chores ... In the grain belt the kitchen was considered to be just as much an integral part of the operation as was the feed lot or the machine shed." ${ }^{34}$ The financial contributions

30. Deglman v. Guarany Trust Co. of Canada and Constantineau 3 D.L.R. 785.

31. Murdoch v. Murdoch 41 D.L.R. (3d) 367, at p.389.

32. Rathmell v. Rathmell 83 D.L.R. (3d) 289.

33. Supra n.l.

34. Rathwell v. Rathwell 83 D.L.R. (3d) 289 at p.292. 
alone would not have been sufficient evidence of an intention to share the beneficial interest. When both financial and labour contributions were taken together, the Supreme Court was prepared to infer that an intention to share the beneficial interest in the property had existed from the moment the Rathwell family enterprise began.

\section{The judgment of Dickson J. in Rathmell v. Rathwell}

Dickson J. concurred in the judgment in Rathwell $\mathrm{v}$. Rathmell ${ }^{35}$ based on resulting trust principles. However he seized the opportunity to elaborate the principles of constructive trusts based on unjust enrichment. Relying on the view expressed by Laskin J., in his dissent in Murdoch, Dickson J. maintained that this doctrine was as equally applicable as the doctrine of resulting trusts to the facts of Rathwell. He declined to accept the criticism of the constructive trust approach expressed by the majority of the Supreme Court in Rathmell. This part of Dickson J.'s judgment was of course obiter. However it was an important stage in the development of the acceptance of the constructive trust based on unjust enrichment in Canada.

Dickson J. recognised the inherent difficulties in finding an agreement between parties in familial circumstances. He explained that, "the property is acquired during a period where there is marital accord. When this gives way to discord, problems arise in respect of property division. There is seldom prior express agreement. There is rarely implied agreement or common intention, apart from the general intention of building life together. It is not in the nature of things for young married people to contemplate the break-up of their marriage and the division, in that event, of assets acquired by common effort during wedlock."36

The charge had been made against the intention based resulting trust as involving "a meaningless ritual in searching for a phantom intent."37 Dickson J. accepted this charge. He then attempted to liberate the law from that meaningless ritual. He expressed the view that the doctrine of the constructive trust based on the concept of unjust enrichment was a more flexible doctrine than the intention based resulting trust. He explained that, "The hallmark of the constructive trust is that it is imposed irrespective of intention; indeed, it is imposed quite against the wishes of the constructive trustee." ${ }^{38}$ Dickson J. was not prepared to impose such a trust without a principled base. He maintained that three requirements were required for the doctrine of unjust enrichment to apply and elaborated them. First, there must be an unjust enrichment. Second, there must be a corresponding deprivation to the claimant of the constructive trust. Third, there must be an absence of any juristic reason - such as a contract or disposition of law - for the

35. Rathwell v. Rathwell 83 D.L.R. (3d) 289, at p.297. See also Frank Bates, (1979) NLJ 288; McCamus and Taman, (1978) 16 Osgoode Hall L. Joum. 741; (1981) 2. 279 Supreme Court L. Rev. 316.

36. Ibid., at p.294. See also Dayer v. Love 67 D.L.R. (3d) 550.

37. Rathwell v. Rathwell 83 D.L.R. (3d) 289 , at p.301.

38. Ibid., at p.305. 
enrichment. If these requirements were fulfilled, a constructive trust could be imposed, providing that a causal relationship could be shown between the disputed property and the unjust enrichment.

Dickson J. accepted that a causal relationship did exist in Rathwell. He rejected the argument that the causal connection existed only between Mr Rathwell's unjust enrichment and a small portion of Mr Rathwell's property, including the family homestead. He reasoned that, "The Rathwells worked and operated all of the lands as one farm, a family farm in which husband and wife shared control and operating responsibilities. Although the causal connection may be clearer when the couples save money to buy the house in which they reside, there is no reason on the authorities, or in principle, why the application of a constructive trust should be confined to a homestead, or to a matrimonial home. The outcome in a matrimonial property case should not depend upon the nature of the property in dispute." 40

\section{The decision in Pettkus v. Becker - constructive trusts based on unjust enrichment}

Less than a decade after it was suggested that the adoption by the Canadian courts of constructive trusts based on unjust enrichment could not happen the Supreme Court, in Pettkus v. Becker, ${ }^{41}$ imposed such a trust. A majority of the Supreme Court finally buried the resulting trust based on the artificial extension of the presumed resulting trust. ${ }^{42}$ Dickson J., giving judgment on behalf of six of the nine members of the Supreme Court, firmly established the doctrine of constructive trust based on unjust enrichment as part of the common law of Canada.

Lothar Pettkus, the appellant, was a bee keeper. He had lived with the respondent, Rosa Becker, for almost 20 years. They had lived frugally. Rosa Becker paid the rent, bought the food and clothing and paid for other living expenses. Lothar Pettkus was thus enabled to save his earnings. He eventually purchased a farm in his sole name, using those savings. He established a bee keeping business. Rosa Becker worked hard in this enterprise for 14 years but received no remuneration for her efforts.

Further properties were purchased in the name of Lothar Pettkus using moneys from the bee keeping business. After a deterioration in the relationship, Rosa Becker departed. Lothar Pettkus gave her $\$ 3,000$, the car and $10 \%$ of the bee hives. She returned three months later and returned the gifts. It was agreed that they would resume their relationship, that a joint bank account would be opened and all receipts from the sale of honey could be deposited in that account. The parties built a new house on land previously purchased in Lothar Pettkus' name.

39. Ibid.; c.f. Ruff v. Strobel 86 D.L.R. (3d) 284.

40. Rathwell v. Rathwell 83 D.L.R. (3d) 289 , at p.308.

41. Pettkus v. Becker 117 D.L.R. (3d) 257. See also A. J. McLean, (1982) 16 U.B.C. L. Rev. 155; (1982) 3. 361 Supreme Court L. Rev.; Bradley, (1982) Fam. Law 21.

42. Ibid. 
The cost of construction was paid for by moneys from the bee keeping business. The relationship between the parties did not survive. Rosa Becker finally departed the property. She claimed a half share in all the properties held in Lothar Pettkus' name.

The Ontario Court of Appeal varied the judgment at trial. It imposed a constructive trust on the respondent. Rosa Becker was to receive a half share in Lothar Pettkus' lands and the bee keeping business. He appealed to the Supreme Court. Dickson J. was given the opportunity he had awaited since Rathwell. He wished to end the judicial quest for that fugitive common intention which had so far been essential to found a resulting trust.

The parties to the dispute in Pettkus v. Becker ${ }^{43}$ had no express common intention. The trial judge had found that Rosa Becker's contribution to the household expenses prior to the acquisition of the first property, "was in the nature of risk capital invested in the hope of seducing a younger defendant into marriage." ${ }^{44}$ Dickson J. found this statement somewhat lacking in gallantry. Ritchie J., in stronger terms, declared it to be gratuitously insulting. The Ontario Court of Appeal had upheld the finding at trial that there was no common intention. Ritchie J. was prepared to disregard that finding. In a majority judgment, he held that a resulting trust had arisen on the facts. ${ }^{45}$ But Dickson J. was not prepared to overrule the finding of the trial judge and the Ontario Court of Appeal.

There could not have been a more opportune moment for the introduction of the doctrine of unjust enrichment into familial property disputes. The fact-situation clearly demanded a remedy. The evidence was such that a resulting trust based on an inferred common intention from financial contributions, could have been imposed had it not been for the earlier findings of the trial judge and the Ontario Court of Appeal. ${ }^{46}$

Dickson J. reiterated the principles of unjust enrichment which he had laid down in dicta in Rathwell. Three requirements had to be satisfied to find an unjust enrichment, an enrichment, a corresponding deprivation and the absence of any juristic reason for the enrichment. For the court to impose the remedy of a constructive trust based on unjust enrichment there must be a casual relationship between the unjust enrichment and the disputed property. ${ }^{47}$ Lothar Pettkus had been enriched by Rosa Becker's nineteen years of unpaid labour. She had been correspondingly deprived during that time. The third requirement was fulfilled, according to Dickson J., if "one person in a relationship tantamount to spousal prejudices herself in the reasonable expectation of receiving an interest in the property and the other person in the relationship freely accepts benefits conferred

43. Ibid.

44. Ibid.

45. Ibid.

46. Ibid.

47. Ibid. See also D. Waters, Lam of Trusts of Canada, 2nd. Ed. (1984). 
by the first person in circumstances where he knows or ought to have known of that reasonable expectation." 48 This third requirement implies that once a reasonable expectation comes to the knowledge of the legal title holder he is under a duty to refuse the contribution of the claimant. If he accepts it, he has acquiesced in the claimant's expectation and must give effect to it. The language in which the third requirement is couched is reminiscent of the English concept of proprietary estoppel. $^{49}$

It can reasonably be questioned whether this third requirement is little more than "common intention" by another name. If the claimant must have a reasonable expectation that she would receive an interest in the legal title holder's property and the latter must know or ought to have known of that expectation, there would appear to be a requirement of an implied common intention. For if the title holder does not reject the contribution he is implying that he shares the claimant's expectation concerning his property. The Canadian Courts have not accepted such an interpretation. A liberal view of this third requirement has been taken. The burden of proof is on the legal title holder to demonstrate that his enrichment, at the expense of the claimant, was without knowledge of the claimant's expectation. ${ }^{50}$ If he cannot satisfy this burden of proof the courts have been prepared to impute the necessary reasonable expectation even where the claimant has clearly not given any thought as to what was her expectation. ${ }^{51}$ By imposing a principled basis for the constructive trust, Dickson J. was able to evade the accusations of administering palm tree justice which were levelled at Lord Denning M.R.'s attempts to impose constructive trusts where justice, equity and good conscience required it. ${ }^{52}$

Once the concept of a constructive trust based on unjust enrichment had become accepted law in Canada, the way was opened for the recognition of domestic contribution as unjust enrichment.

\section{The recognition of domestic contribution as unjust enrichment in Sorochan} v. Sorochan

The Supreme Court in Sorochan v. Sorochan ${ }^{53}$ finally recognised that domestic contribution could equally unjustly enrich a legal title holder as financial contributions. The parties in Sorochan, Mary and Alex Sorochan, had lived

48. Pettkus v. Becker 117 D.L.R. (3d) 257. If the relationship is of short duration the courts have not been prepared to grant a constructive trust remedy: see Neiderberger v. Memnook 130 D.L.R. (3d) 353. Where the relationship is actually spousal the parties are more likely to use matrimonial legislation (see R.SO 1980 c.152) but there remain circumstances where spouses may need to plead a constructive trust: see Rankin, (1984) 17.72 Ottama L. Rev. 79.

49. A comparison of the doctrine of proprietary estoppel and the doctrine of unjust enrichment has been made in an unpublished thesis by the author of this article.

50. See Girard, (1983) 28 McGill L. Foum. 977, at p.1000.

51. This was indeed the case in Pettkus v. Becker itself.

52. See Hodkinson, (1983) 47 Conv. (N.S.) 420.

53. Sorachan v. Sorachan 29 D.L.R. (4th) 1. 
together in a de facto relationship for 42 years. They worked the family farm together and produced six children. Mary Sorochan did all the domestic labour associated with running the household and caring for the children. She also laboured long hours alone on the family farm whilst her de facto husband worked as a travelling salesman. The Alberta Court of Appeal had reversed the trial judge's finding of a constructive trust in favour of the appellant. It held that there was no casual connection between her contribution of labour and the acquisition of the property by the respondent.

Judgment in the Supreme Court was given by Dickson C. J. C. He did not differentiate between the appellant's domestic contribution to the household and her labour on the farm. He held that the respondent had derived a benefit from both types of labour. According to Dickson C. J. C., this benefit included valuable savings from having essential farm services and domestic work performed by the appellant without having to provide remuneration. Dickson C. J. C. was reinforced in his refusal to differentiate between domestic contribution and other types of labour by the judgment of the Alberta Court of Queen's Bench in Herman v. Smith. ${ }^{54}$ This case concerned a claim of a constructive trust based on a contribution of domestic labour alone. The Alberta Court held that the rendering of normal spousal services, by the woman, amounted to a valuable service which resulted in an enrichment to the man and a corresponding deprivation to the woman. In the Sorochan Case Mary Sorochan was equally held to have enriched her de facto husband to her corresponding deprivation. There was no juristic reason for the enrichment. The Supreme Court held that there was no obligation contractual or otherwise by Mary Sorochan to perform domestic or other labour. She had a reasonable expectation of receiving some benefit in return for her $\mathbf{4 2}$ years of labour. She had asked Alex Sorochan to marry her and to place property in her name. These two incidents convinced Dickson C. J. C. that Alex Sorochan ought to have known that his de facto wife had a reasonable expectation of obtaining a share in the land.

Alex Sorochan already owned the disputed land when Mary Sorochan went to live with him. It was, therefore, argued by counsel for the respondent, that there could be no causal relationship between her contribution of domestic and farm labour and his acquisition of the property. The Supreme Court rejected this narrow view as treating "a particular manifestation of the rule as the rule itself." It articulated a more general causal connection test. There should merely be a clear link between the contribution and the disputed asset. The courts must ask whether the contribution is sufficiently substantial and direct to entitle the plaintiff to a share of the property in question. Cary J. A., in Murray v. Roty, ${ }^{56}$ a decision of the Ontario Court of Appeal, had already employed the general causal connection

54. Herman v. Smith (1984) Alta L.R. 2nd 90. See alsa Lamrence v. Lindsey (1982) 21 Alta L.R. (2nd) 141.

55. Sorochan v. Sorochan 29 D.L.R. 4th 1, at p.8.

56. Murray v. Roty 147 D.L.R. (3d) 438 , at p.445. 
test. He explained that domestic activity maintains and preserves the property. In that sense it is substantial and direct. It also releases the legal title holder from having to pay for domestic help, or from having to do it himself. The money or time saved permits him to improve and maintain his property either by payments to another, using the money saved, or by his own efforts, using the time saved. ${ }^{57}$

It would seem from the Sorochan case that the principle of unjust enrichment has been broadened. Will there be any relationship involving joint participation in a communal, familial venture which will be able to evade the imposition of a constructive trust?

\section{Conclusion}

The Canadian Supreme court has finally recognized that domestic contribution is of equal value as financial contribution in trusts of property in the familial context. It is a realistic acknowledgement that living in a familial relationship is a common enterprise; each member contributes according to his abilities and to the needs of the other members of the household. If the common enterprise breaks down, its property will be distributed in accordance with those contributions; financial contributions will not be valued more highly than domestic contributions.

Lord Simon of Glaisdale, at one time President of the Family Division of the English High Court, had already recognised, in an address to the Holdsworth Club of Birmingham University, more than 20 years ago, that "Men can only earn their incomes and accumulate capital by virtue of the division of labour between themselves and their wives. The wife spends her youth and early middle age in bearing and rearing children and in tending the home; the husband is thus freed for his economic activities. Unless the wife plays her part the husband cannot play his. The cock bird can feather his nest precisely because he is not required to spend most of his time sitting on it." 58

The Canadian Supreme Court has acknowledged the truth of Lord Simon's view of the co-operative nature of the familial enterprise. Will other Commonwealth jurisdictions be prepared to adopt the Canadian approach to the constructive trust in the familial context? ${ }^{59}$ Such an adoption would be a fitting memorial to the death of Rosa Becker on the legal battle ground of the family home.

57. C.f. A.J. Oosterhoff, (1979) 58 Can. Bar Rev. 356, at p.370.

58. "With All My Worldly Goods ..." (Address to the Holdsworth Club, University of Birmingham, 20th March 1964), p.32.

59. The New Zealand Court of Appeal, in Haymard v. Giordani [1983] N.Z.L.R. 140, at p.153 per McMullin J., accepted that the Canadian approach had much to commend it. It was able to find a constructive trust based on an express common intention and therefore found it unnecessary to consider whether the doctrine of unjust enrichment should be given a place in the Law of New Zealand. See also Easton, (1982) 12 V.U.W.L.R. 159; Goff and Jones, The Law of Restitution, 3rd Ed. (1986); (1983) Conv. (N.S.) 420. 